\title{
Pro-poor Institutions: Creating Exclusive Rights to the Poor Groups in Community Forest Management
}

\author{
Sushma Bhattarai*, Prakash Kumar Jha* and Niraj Chapagain* \\ Livelihoods \& Forestry Programme (LFP), Nepal \\ Corresponding author: bhattarai.sushma@gmail.com
}

\begin{abstract}
In spite of the widely accepted success of Community Forestry in reviving degraded land, it is still seen as being unable to provide tangible benefits to the poor. This paper illustrates that through continuous sharing, deliberation and negotiation among the poor and non-poor members of Community Forest User Groups (CFUGs), management of community forests can be made far more equitable than the usual scenario. Drawing from the experience on the processes and outcomes of Livelihoods and Forestry Programme (LFP), this paper brings empirical evidence of how facilitation support has enabled the poor to have more equitable access to community forests. Three key pro-poor institutional arrangements resulting from the facilitation process include: a) establishing special use rights arrangements within CFUGs for the poor, b) pro-poor silvicultural practices, and c) equitable forest product and benefit distribution mechanisms. The paper suggests some changes in policy and practice to institutionalise these outcomes.
\end{abstract}

Key words: land allocation, forest management, social mobilisation, livelihoods

\section{INTRODUCTION}

Community based forest management institutions are considered to be effective solution to the problems of sustainable management of commons. However, current community-based forest management institutions are often unable to provide a significant contribution to the livelihood of poor and marginalised people due to their limited influence in addressing broader socio-economic and distributional issues (Branney and Yadav 1998). Though the community forestry programme has been widely accepted as being successful in reversing the past trends of deforestation in the hills of Nepal (Kanel 2004), the needs of the poor have often been neglected and hence there are limited livelihood impacts (Dev et al. 2003). Moreover, the amount of forest products harvested at present is insufficient to meet the needs of the users (Malla 2000). In addition, the issue of ensuring equitable use of forests products within the community has not been clearly demonstrated (Branney and Yadav 1998). The issues of equity and poverty within community forestry have not been adequately addressed (Timsina and Luintel 2003). Therefore, streamlining the benefits from forest towards livelihood enhancement (particularly poverty alleviation) and strengthening good governance for equitable performance are the key areas for improvement (Kanel 2004). Equity, in general term, entails fair distribution of resources, rights, opportunities and wealth among people over time (Agarwal 2001, Kothari 1999). Despite participatory innovations, approaches to natural resource management are yet to devise institutional mechanisms that allocate more resources than the business as usual to disadvantaged groups (Timsina and Paudel 2003).

This paper illustrates that through continuous sharing, deliberation and negotiation among the poor and non-poor members of CFUGs, management of community forests can be made more equitable than the usual practices. It is demonstrated through the experiences of Livelihoods and Forestry Programme (LFP) in the western hills and the Terai of Nepal. We provide empirical evidence on the process and outcome of how external facilitation support enabled the poor to have more equitable access to community forests. We discuss a particular form of institutional innovation that entails assigning exclusive use 
right to the identified groups (of the poor) within the Community Forest User Groups (CFUGs), developing pro-poor silvicultural practices, and formulating equitable rules for forest products distribution and benefit sharing. Data collection methods used for this paper include: literature review, informal discussions, field visits and case study.

\section{BACKGROUND}

Based on Forest Act 1993 and Forest Regulations 1995, the government transfers responsibility to CFUGs for managing parts of national forests. The transfer of rights includes the right to use forest products in a sustainable way with the ultimate policy objective of improving livelihoods of rural communities (HMGN 2002). CFUGs have been recognised as social institutions, legal entities and self-governing autonomous bodies which have legal rights to formulate their constitution and to take decisions regarding Community Forestry (CF) management (Adhikari 2001). They hold the legal right to claim support services from the District Forest Office (DFO), and are also free to collaborate with other organisations (SpringateBaginski et al. 2003). With such institutional arrangements, Nepal's community forestry has now been regarded as a successful development innovation in the country and outside.

Despite such successes, issues of equity and inclusion in CF still remain controversial. Since all the users within CFUGs do not belong to any particular wellbeing category, benefit distribution mechanisms based on equality may not fulfill the requirements of the poor groups. Malla et al. (2003) found that wealthier households appear to benefit more, in terms of forest product distribution and community forest management than the poor. This is because most CFUGs distribute products equally between households even though richer households may have never collected items such as fuelwood from communal forest, and poorer households are forced to make up their requirements from other, generally the more distant government-managed forests.
Nepalese society is socially, economically and culturally diverse, and a single community making up a CFUG comprises of multiple castes, ethnicities, economic classes and other culturalpolitical identities. This heterogeneity has created deep inequities within the society that are manifested in unequal power relations, which are defined by caste, class, gender and regional settlement (Bista 1991, Rai-Paudyal 2008). These inequities are further compounded by the inadequate support of government, gap in policy implementation, and poor governance at the community level.

Recognising these issues of equity, there is now greater attention towards how CF can make better impact on the livelihoods of the poor. CF has moved beyond its original goal (fulfilling basic forestry needs) as stipulated by the Master Plan for the Forestry Sector 1989, and has been integrated with the national agenda of poverty reduction by increasing income generation opportunities through decentralised and sustainable management of forests (NPC 2007). Moreover, the national policy focus is increasingly on reducing poverty, and community forestry as a means for both sustainable forest management and poverty reduction has been well-recognised by the national policy (NPC 2007). In the light of such policy directions, programmes and projects are increasingly focussing on developing methods and strategies to enable the poor and deprived groups to have equitable access to community forests (NPC 2003).

There are several projects and programmes with the stated goals to uplift the socioeconomic conditions of the poorest and vulnerable sections of society. LFP is a bilateral programme funded by Department for International Development (DFID) and is implemented in fifteen districts of Nepal. It aims to reduce vulnerability, improve livelihoods of the poor and excluded rural people through the financial, social and technical interventions. From 2001, LFP is providing its support to develop forestry sector and accordingly improve livelihoods of people in the selected districts: Dhankuta, Sankhuwasabha, Bhojpur and 
Terhathum of the Koshi Hills; Baglung, Parbat and Myagdi of western Dhaulagiri zone; Rupandehi, Nawalparasi and Kapilvastu of Terai Lumbini zone; and Salyan, Rukum, Pyuthan, Rolpa and Dang of Mid-western Rapti zone.

\section{LIVELIHOODS AND FORESTRY PROGRAMME'S ANIMATION AND SOCIAL MOBILISATION FOR PRO- POOR INSTITUTIONS}

One of the outputs of Livelihoods and Forestry Programme (LPF) is that "Poor and excluded groups actively participate in and benefit from involvement in the forestry/ Natural Resource Management (NRM) sector". Achieving this requires addressing complex chains of exclusion from local community to national level. In this context, a Pro-poor and Social Inclusion (PPSI) strategy has been developed, which is implemented through Animation and Social Mobilisation (A/SM) activities. A/SM activities are implemented by LFP as a part of its mainstream programme with government and Non Government Organisation (NGO) partners by mobilising trained Local Resource Person (LRP) as animators. LRPs are selected by CFUGs from within or neighboring communities, with good knowledge about the local contexts. $\mathrm{A} / \mathrm{SM}$ aims to mobilise and empower community members to more effectively participate in community activities (Box 1). It aims to strengthen the functioning of CFUGs, and improve the livelihoods of poor and excluded people whose needs and aspirations are often marginalised in the decisions of CFUG Executive Committees (ECs).
For more equitable benefit sharing, LRPs, and other animators /social mobilisers work with groups and individuals within CFUGs from different socio-economic backgrounds. A key strategy used is to influence local elites (such as high caste males) who control local resources and empower the poor and excluded through raising awareness on equitable rights to claim benefits. LRPs and animators who are currently supported by LFP and communities have received training in several key aspects, including forest management techniques and basic social inclusion issues. The strategy of nurturing and mobilising local change agents has been effective in dealing with the increasing demands from user groups for technical services, as well as addressing social and economic equity issues within the CFUGs. In areas where LRPs have worked for a couple of years, it is found out that CFUGs have become much more empowered and institutionally capable than they were previously. Some of the CFUGs supported by LRPs under A/SM have been asked to support other CFUGs, and have started to demand their recognition as service providers. Many CFUGs have collaborated with agencies other than forestry for many services they require. Non-governmental service providers are increasingly becoming important service providers even in conflict situation (Hayu and Pokharel 2004). 


\section{Box 1: Process and activities for $\mathrm{A} / \mathrm{SM}$ of community groups}

The process of $A / S M$ involves four main phases:

Phase One: Building awareness and confidence

- Support poor and excluded people to understand their rights and voice their needs

- Sensitise and convince local elites and key CFUG leaders who are relatively open to change

- Facilitate CFUGs to hold assemblies and meetings

- Facilitate community assessments through well-being ranking

- Create opportunities for open discussion of problems and needs for plan preparation.

Phase Two: Organising groups and preparing or revising plans

- $\quad$ Facilitate the formation of tole (hamlet) / interest groups and Poor and Excluded (P\&E) focused planning

- Facilitate CFUGs to allocate resources to the P\&E

- Support amendment of Operational Plans (OPs), and Constitutions to make them P\&E sensitive

- Support preparation of action plans based on OPs, and

- Support preparing Constitutions so that interventions are more systematic and P\&E-focused

- Facilitate planning based on the needs of tole /interest groups

- $\quad$ Provide training on record keeping, accounting, leadership, and forest management.

Phase Three: Provide tangible benefits and assets

- Support and facilitate the CFUGs to implement the plans, OPs, and Constitutions

- Seek funding opportunities for community infrastructure as an entry point to encourage the participation of the whole community

- $\quad$ Support creating increased assets and opportunities for P\&E.

Phase Four: Building sustainability and linkages

- Recruit and train volunteer animators

- Create linkages to services for community development and livelihoods opportunities

- Create linkages to technical forestry service providers, such as LRPs and Range Posts

- Make animation programme the responsibility of VDCs by facilitating local resource mobilisation.

Source: LFP 2007

\section{FINDINGS}

Below we outline the key outcomes of $A / S M$ activities toward inclusive and equitable management of community forestry. We identify at least four positive outcomes: creation of equitable property rights arrangements, empowerment of the poor and excluded groups to have better access to common pool resources, development of propoor forestry and silvicultural practices, and equitable rules of forest product and benefit distribution.

\section{Creation of Special Use Rights Arrangements within CFUGs for the Poor and Excluded Groups (Land Allocation Mechanisms)}

$\mathrm{A} / \mathrm{SM}$ activities have been found to be effective to provide poor and excluded groups an opportunity to benefit from common property resource management by facilitating the institution of special use rights arrangements, mainly through 'Land Allocation' to the poorer groups. The purpose of land allocation mechanism is to enable the poor and landless to 
cultivate cash or food crops. This has helped to improve the socio-economic condition of the poor and excluded groups who are below the poverty line. It also promotes better land use for the economic and ecological regeneration and creates environment for sustained participation of P\&E in community forestry.

The key strength of CF land allocation lies in promoting the effective management of barren land and increasing its productivity; thereby improve the livelihoods of the poor, women and Dalits. Since over 10.6 percent of the Nepal's total land area consists of shrub land which is legally referred to as forest (Forest Act 1993), there is plenty of space to provide the shrub land under land allocation provision to the poor. Thus, allocation of community forestry land to the poor for income-generating activities appears to have real potential to improve their livelihoods (LFP 2004a). The process involves regular monitoring of the situation to ensure that the land is used appropriately and effectively, and is very essential for user to make land allocation concept a reality. Moreover, it includes a series of steps from the selection of beneficiary group to the implementation of the programme (Box 2).

\section{Box 2: Process for land allocation}

- Identification of poor family through well being ranking during the time of CFUG constitution preparation along with identification of suitable land area is the first step. This is followed by the official request to the CFUG to allocate land within community forest.

- Discussion takes place among committee members upon the request and presented in assembly after the acceptance. Based on the consensus of the community, a sub-group is formed of the poor and marginalised households identified by participatory well being ranking.

- As the CFUG is the combination of people having different views, it is necessary to change the attitude of those people who do not favour land allocation. Through a series of interactions with LRPs, they develop an understanding that CF land allocation is one of the several poverty reduction mechanisms to be employed by the CFUGs. Oftentimes, proper facilitation is required, including tole (hamlet) level meetings and group discussions to resolve any disputes.

- Identification and selection of bare land, i.e. generally forest having crown density less than $20 \%$, suitable for land allocation within CF. The delineation of such land is done by Range Post (RP) level forestry staff and/or by LRPs.

- After identification of the poor families and suitable land for Land Allocation, an agreement between CFUG and the sub-group of the poor is made. Generally DFO is present and provides facilitating inputs during such agreement. The agreement is signed by CFUG committee and sub-group. Generally, the provision of land allocation is mentioned in OP/Constitution of the CFUG.

- If such agreement is developed after OP formulation or at a time when OP is not being revised, the CFUG informs the DFO about the Land Allocation agreement.

- The process has the potential to raise the awareness of both elite and poor members of the CFUG on more equitable system of benefit sharing from community forestry. The discussion on Land Allocation covers the following points:

$>$ selection criteria of the beneficiary groups

$>$ selection criteria of the land to be allocated

$>$ objective of the CF Land Allocation and its duration

$>$ area, boundaries, and description of the land

$>$ acceptable uses of the land and limitations to the use of land

$>$ systems to share the costs and benefits between the poor users, CFUG, and other stakeholders

$>$ process of withdrawing the allocated land

$>$ system for marketing the product of the land

- After the agreement is made, the sub-group or the poor households begins to utilize the allocated forest land. 
Through land allocation program, poor people have managed and harvested fodder, grass and Non-timber Forest Products (NTFPs). The poor people have in most cases developed selfconfidence and are actively engaged in collective activities to improve their economic status. Moreover, they feel that they are well integrated into the larger community. This has ultimately increased the feeling of ownership in CF process, mainly through an increased participation in CF processes.

The selection of poor household is an important step for land allocation. The household are selected through well being ranking. Since there are often a large number of poor families than the land available for lease, appropriate facilitation is required to make common understanding while selecting the few eligible households. Table 1 provides general criteria for CF land allocation as practiced in the Rapti LFP area. These include not only those related to the selection of households but also the ones concerning the selection of forest land and choice of species to be planted. Similarly, Box 3 provides an example of a CFUG that allocate the forest land for the poor.

Table 1: Criteria for CF Land Allocation

\begin{tabular}{|c|c|c|}
\hline Selection of forest land & Household selection & Selection of plantation species \\
\hline $\begin{array}{l}\text { Community forest land } \\
\text { without trees }\end{array}$ & $\begin{array}{l}\text { Poorest households in } \\
\text { wellbeing ranking }\end{array}$ & $\begin{array}{l}\text { Potential to give tangible benefits } \\
\text { and a quick return on investments } \\
\text { within a short span }\end{array}$ \\
\hline $\begin{array}{l}\text { Suitable condition and area } \\
\text { for cultivation }\end{array}$ & $\begin{array}{l}\text { Disadvantaged people: poor, } \\
\text { Dalits and women }\end{array}$ & Linked to livestock raising \\
\hline $\begin{array}{l}\text { Accessible to beneficiary } \\
\text { group }\end{array}$ & $\begin{array}{l}\text { Appropriate number of } \\
\text { households for the land } \\
\text { available }\end{array}$ & Linked to market demand \\
\hline $\begin{array}{l}\text { Facilities for the cultivation } \\
\text { of species: water and shelter }\end{array}$ & $\begin{array}{l}\text { Beneficiaries should reside } \\
\text { closely together and be able to } \\
\text { function as a group }\end{array}$ & $\begin{array}{l}\text { Linked to capabilities of beneficiary } \\
\text { households }\end{array}$ \\
\hline $\begin{array}{l}\text { At least } 1 \text { hectare (ha) for } 4 \\
\text { households }\end{array}$ & & $\begin{array}{l}\text { Must not be annual crops, but can } \\
\text { be perennial species }\end{array}$ \\
\hline
\end{tabular}

Source: LFP 2004b

After the completion of the agreement between CFUG committee and beneficiary group, the given plot of land is divided among each household. In some cases, the users use the land collectively rather than dividing the land amongst the individual households, with all the members contributing and sharing the benefit equally. Experience shows such group based activity helps strengthen collective spirit and power. The most common use of the land is for grass and fodder for livestock. In some cases, they have planted broom grasses and NTFPs like kurilo (Asparagus racemosus), and seto musli (Chlorophytum esculentum) for long-term benefits. 


\section{Box 3: Tarepahar Community Forest Users Group}

Tarepahar CFUG of Dhanbang VDC covers 47 households (HHs). Among them, $9 \mathrm{HHs}$ belong to rich category, $10 \mathrm{HHs}$ to medium, $10 \mathrm{HHs}$ to poor and $18 \mathrm{HHs}$ to very poor category, as per the well being ranking criteria. With the facilitation inputs from DFO and LFP staff, the users agreed to allocate CF land for the poor (letter of contract between land allocation group and CFUG committee is given below). For this $20 \mathrm{HHs}$ identified as poor formed Saunepani cardamom production group. The group is given 2.26 ha of CF land through the land allocation agreement. The contract was signed in 2007, and they now have planted cardamom in the allocated land.

\section{Tarepahar Community Forest User Group \\ Dhanwang-3, Kapurkot, Salyan Contract Letter}

This agreement is made today 25 June 2007 (2064/03/11 BS) between Tarepahar CFUG (hereafter referred as "First Party") and Saunepani Cardamom Cultivation Group (hereafter referred as "Second Party") to provide community forest area to the group for cultivation of cardamom as decided on 9 June 2007 (2064/02/26 BS). The group agrees on abiding by the terms and conditions mentioned hereunder:

Terms and Conditions:

1. Saunepani cardamom production group will be remained as subgroup of Tarepahar CFUG.

2. Saunepani cardamom production group can build network between district and local level for coordination and marketing, if necessary.

3. The first party should provide its forest area to 20 households of second party to conduct income generating activities like cardamom cultivation and pear grafting on male plants for 10 years in rent.

4. The first party will provide 2.26 ha of block number 2 .

5. The second party can use the hundred percent of products produced/profit made while conducting income generating activities in forest area for 5 years. After that period, the second party will deposit 15 percent of the total revenue in the account of first party from $6^{\text {th }}$ year.

6. After $10^{\text {th }}$ year, first party can either continue or discontinue the agreement based on consensus and mutual agreement. The sovereign right to continue and discontinue depends upon the first party only.

7. The second party shall include poor, Dalit and disadvantaged groups as its member if any of the households decide to discontinue through a written statement to the second party, in accordance with the recommendation of the first party.

8. Whatever mentioned in this agreement letter, both the party shall follow the rules and regulations set by the government.

9. First party will have the full rights over all the rest NTFPs, wild plants etc. that exist inside the forests.

\section{Saunepani Cardamom Cultivation Group}

Name:

Designation:

Signature:

Date:

\section{Community Forest User Group}

Name:

Designation:

Signature:

Date: 


\section{Empowerment of the Poor and Excluded}

Social mobilisation aims to empower the disempowered and voiceless and also aims to enable them to demand for their rights, understand responsibilities so that they can receive equitable benefits from the programmes implemented in their areas. Therefore, high quality and effective facilitation is necessary to change people's perceptions and behavior, and to enable them to act proactively to empower P\&E. Since P\&E people typically lack access to arable private land, they often depend more on community forestry resources for their livelihoods. In view of the fact that empowered CF users are better positioned to negotiate more equitable and mutually beneficial forest use and demand their rights, different awareness raising and empowerment activities are conducted to this end. These include household visits, well being ranking, formation of sub groups/ interest groups, propoor and social inclusion trainings, and the like. Such activities have been found empowering the poor, women and disadvantaged members in getting organised to raise their voice collectively and hence changing the 'rule of the game' around resource management.

Started mainly for the production of fodder as a silvo-pastoral model of agroforestry system, land allocation in later years has been used for NTFPs and other cash crop cultivation, thatch grass production, and other cash crops. In the eastern hill districts of Dhankuta, Terhathum, Sankhuwasabha and Bhojpur land allocation has been practised for cash crop such as cardamom cultivation. It has also been practised for complementing supply of raw materials to local forest based enterprises such as lokta (Daphne species) and Argeli (Edgeworthia gardneri) cultivation for paper enterprises in Sankhuwasabha and Terhathum district, citronella cultivation for supplying citronella to the locally established citronella distillation plant at Leuti Phedi of Dhankuta district. Similarly, in some areas commercially valuable NTFPs such as Kurilo (Asparagus recemosus), Chiraito (Swertia chiraita), Seto Musali (Chlorophytum esculentum), Kalmegh (Androtraphis panicunapa), Timur (Zanthoxylum armatum), Lapsi (Choerospondias axillaries), and Ritha (Sapindus mukorossi) have been cultivated.

Till the end of 2008, in LFP project area 698.02 ha of community forest land has been allocated under land allocation scheme to carry out different income generation activities (Table 2). A total of 7317 households in 621 CFUGs are benefitted. Among them $7123 \mathrm{HHs}$ (97 percent of total land allocated $\mathrm{HHs}$ ) belong to poor and very poor categories (Table 2). If this mechanism is replicated on a large scale, there is a tremendous potential for community forests to improve the livelihoods of poor people in Nepal.

Table 2: Land Allocation

\begin{tabular}{|l|l|l|l|l|}
\hline SN & Area & $\begin{array}{l}\text { No of } \\
\text { CFUGs }\end{array}$ & $\begin{array}{l}\text { Allocated } \\
\text { CF area } \\
\text { (ha) }\end{array}$ & Total HH \\
\hline 1 & East (4 districts) & 274 & 336 & 2305 (Dalit 346, Janajati 1151, and Others 808) \\
\hline $\mathbf{2}$ & West (3 districts) & 95 & 168.13 & 865 (Dalit 453, Janajati 162, and Others 250) \\
\hline 3 & Terai (3 districts) & 19 & 30.57 & 374 (Dalit 92, Janajati 197, and Others 85) \\
\hline 4 & $\begin{array}{l}\text { Midwest (5 } \\
\text { districts) }\end{array}$ & 233 & 163.32 & 3773 (Dalit 633, Janajati 2247, and Others 893) \\
\hline $\begin{array}{l}\text { Total } \\
\text { Total }\end{array}$ & 621 & 698.02 & 7317 (Dalit 1524, Janajati 3757, and Others 2036) \\
\hline
\end{tabular}

Source: LFP 2008a 
In Fiscal Year (FY) 2005/06 (2062/63) total 59 CFUGs have allocated 26 ha of land to 853 households in Dang district. Total 107 households of Dalit, 542 households of disadvantaged Janajati and 166 households of other category are benefited. Among them 728 (85 percent) households belong to the poor group (Table 3 ). These groups have already started harvesting their products.

Table 3: Land Allocation Managed during FY 2005/06 in Dang District

\begin{tabular}{|l|l|l|l|l|}
\hline SN & Species name & Scientific name & No. of seedling & Plantation area (ha) \\
\hline 1 & Aswogandha & Withania somanifera & 22,000 & 26 \\
\hline 2 & Kalemegh & Andrographis paniculata & 15,000 \\
\hline 3 & Kurilo/satabar & Asuparagus racemosus & $7,38,028$ \\
\hline 4 & Sarpagandha & Rauwolfia serpentina & 6,000 \\
\hline 5 & Seto musli & Chlorophytum borivillianum & $416 \mathrm{~kg}$ seeds & \\
\hline
\end{tabular}

Source: LFP database, Dang

As a result of providing degraded land within CF on lease to poor people, such land has been put into productive use. Due to additional inputs managed by the groups (such as regular irrigation, composting and other farming operations), it is observed that the degraded barren and the waste lands have been rehabilitated with regeneration of some of the valuable species. Apart from raising incomes locally, land allocation scheme has also contributed to CFUG incomes, especially in the later stages of the degraded land management.

\section{Pro-poor Forestry and Silvicultural Practices}

In practice, many of the CFUGs in the LFP area seemed to be protection oriented, partly because of the lack of necessary services. Until recently, and to some extent till to date, service providers have not been able to provide required services to the CFUGs as per their needs and management objectives as they lacked practical experiences in community forest management. Traditional protection oriented forest management practices were prevalent in most of the community forests. The communities also at times treated establishing CF as securing right over forests, without proactive planning and management activities. Quite often the everyday need of fuelwood and fodder was fulfilled from nearby national forests, whilst CFs were put under protectionist regime.

But with assistance from LFP supported technical forest management services, CFUGs are gradually moving towards more active forest management. It is the outcome of external intervention for last several years by LFP, DFOs and other partners (Box 4). Field based training/ coaching on Active Forest Management (AFM) along with regular silvicultural operations are now practiced in most of the CFs in LFP area. In general, the objectives of CFUGs in adopting AFM are: to ensure regeneration, to maintain forest diversity, to increase supply of forest products, and to optimise forest resources for the improvement of livelihoods of poor users through sustainable NTFP management, land allocation, and forest and non-forest based enterprise development. 


\section{Box 4: Naulobikas CFUG, Salyan}

Traditional protection mechanism was prevalent in Naulobikas CFUG of Garpa VDC, Salyan. "It was very difficult to me to make them understood about the importance and advantages of forest management which took long time" says Kamala Gharti, LRP in Garpa VDC in a recent visit by the lead author of this paper in the area. The communities have protected their forest for many years. They did not agree to fell even the dying or deformed trees with the misconception that this will create deforestation. In order to sensitise the group on the relevance of active forest management, household visit was done by LRPs to raise awareness about forest management. The LRP responded to was question on how the process was done: "I first convinced CFUG executive committee to carry out silvicultural operations in their CF, and then those committee members convinced other users". It was gathered from the interviews that after performing thinning, pruning and weeding operations in the particular block of forest, regeneration began on the bare areas. Apart from this, users obtained fuel wood from silvicultural operations. Undertaking silvicultural practices also saved time for fuelwood collection as they had to go to adjoining forest for fuelwood collection which took long time in the past. Now communities are quite convinced on the active management of forests. "Forest is like an agricultural crop, we should remove unwanted weeds and diseased trees to create favorable condition for the regeneration" said Mr. Ganesh Budamagar, President of Naulobikas CFUG.

Besides, an increasing number of CFUGs have begun to undertake forest management activities such as thinning, pruning, removal of mature and unwanted species for the plantation and natural regeneration of important species, block forest management, and demonstration plot establishment. In this way, the situation of forest management is changing with the intervention and support of LFP, DFO and partner organisations through $\mathrm{A} / \mathrm{SM}$ activities. The process of active forest management was initiated since last four years in five district of Midwest area (Salyan, Rukum, Rolpa, Pyuthan and Dang). The total area of forest handed over as CF is 195033.53 ha and is managed by 1730 CFUGs (Table 4).

Different awareness raising activities from household visit to onsite coaching of active forest management crafted awareness among communities to make effective and sustainable use of forest resources. Experience shows that such activities bring positive changes in the approach and working modalities of community people (Table 5) (Khanal 2002, Kanel et al. 1999, Neupane 2000, Singh 2002, Wagle 2002).

Table 4: AFM in Mid-west Areas

\begin{tabular}{|l|c|c|c|c|c|c|}
\hline & Dang & Pyuthan & Salyan & Rolpa & Rukum & Total \\
\hline CFUG (No.) & 437 & 324 & 345 & 318 & 306 & 1730 \\
\hline Area handed over as CF ( ha) & 90999.96 & 38581.57 & 30114 & 23410 & 11928 & 195033.53 \\
\hline CFUG involved in management & 265 & 181 & 255 & 165 & 120 & 986 \\
\hline CF area Managed (ha) & 7221 & 2000 & 2640 & 389 & 837 & 13088 \\
\hline Management area / CFUG & 27.25 & 11.05 & 73.91 & 51.89 & 39.22 & 56.99 \\
\hline CFUG involved in Management (\%) & 60.64 & 31.10 & 52.60 & 9.97 & 42.10 & 40.26 \\
\hline
\end{tabular}


Table 5: Forest Management Practices adopted by CFUGs

\begin{tabular}{|c|c|}
\hline SN & Before A/SM \\
\hline 1 & Protection oriented \\
\hline 2 & Protection of unwanted species \\
\hline 3 & Protection of mature and deformed trees \\
\hline 4 & Harvesting of dead and fallen trees \\
\hline 5 & $\begin{array}{l}\text { No/limited practice of NTFPs } \\
\text { management }\end{array}$ \\
\hline 6 & No programme for land allocation \\
\hline
\end{tabular}

Source: LFP 2006

In the past, the Constitutions and OPs of CFUGs heavily focused on the protection of forest. The revision and preparation of new OPs for community forests has led to improvement in both processes and contents, with new plans containing comprehensive activities related to both technical forest and NTFPs management practices and social issues such as gender, social equity and income generation. Several propoor provisions are now instituted in the

\section{After A/SM}

More production oriented

Removal of unwanted species

Removal of mature trees

Harvesting of all types as per the calculation of sustained annual yield

Many initiatives for NTFPs management

Land allocation within CF for IGA support to P\&E

Constitutions and OPs of CF with an aim to maintain equity in CF (Box 5).

With increased focus on P\&E, women, and Dalits, their participation has significantly increased in decision making forums. According to PCR (2008), 57 percent of the poor have participated in meetings and assemblies. "After partnership programme, we have been able to express women's voices and share our feelings in the committee meetings" said Harikala B.K., member of Naulobikas CFUG Committee.

\section{Box 5: A few examples of pro-poor and inclusive provisions in Constitutions and OPs of CFUGs (PCR} 2008)

- Subsidised prices of forest products to the identified poorer groups;

- Reservation for the poor, women and Dalits in Community Forest User Committees and decision-making bodies;

- Special provision for the distribution of forest products to vulnerable groups (for example, charcoal to blacksmith), victim of natural disaster and single women and conflict victims;

- Allocation of CFUG funds and low interest loans for IGA;

- $\quad$ Forest resource management with allocation of CF land to poor users;

- Scholarship to children from pro-poor family.

\section{Creation of employment through active forest management}

Based on data collected from 617 CFUGs from five districts of Midwestern region, it has been revealed that 742,082 person-days employment was generated to very poor and poor groups, in addition to 6,721 person-days of employment to other groups (Table 6). There are opportunities of employment in CFUGs as forest watcher and wage labor during various silvicultural operations. The CFUGs-supported poor include timber worker, nursery technician/ nursery naike (head), fuel wood seller, resin collectors and others. 
Table 6: Paid Employment Generated by CFUGs in Mid-west Areas during Fiscal Year 2007-8

\begin{tabular}{|c|c|c|c|c|c|c|c|c|c|}
\hline \multirow{2}{*}{$\begin{array}{l}\text { Types of } \\
\text { work }\end{array}$} & \multirow{2}{*}{$\begin{array}{l}\text { Based } \\
\text { on } \\
\text { no. of } \\
\text { CFUG }\end{array}$} & \multicolumn{5}{|c|}{ Paid employment person Days } & \multirow{2}{*}{$\begin{array}{l}\text { Very } \\
\text { poor \& } \\
\text { poor }\end{array}$} & \multirow[t]{2}{*}{ Other } & \multirow[t]{2}{*}{ Total } \\
\hline & & Dalit & Janajati & Minority & Other & Total & & & \\
\hline $\begin{array}{l}\text { Forest } \\
\text { manageme } \\
\text { nt }\end{array}$ & 370 & 117921 & 290028 & 11025 & 164242 & 583216 & 549260 & 33956 & 583216 \\
\hline $\begin{array}{l}\text { Nursery } \\
\text { manageme } \\
\text { nt }\end{array}$ & 87 & 3375 & 44411 & 261 & 8364 & 56411 & 53930 & 2471 & 56401 \\
\hline $\begin{array}{l}\text { Others } \\
\text { (Resin and } \\
\text { NTFP) }\end{array}$ & 160 & 57623 & 60452 & 0 & 68286 & 186361 & 138892 & 30994 & 169886 \\
\hline Total & 617 & 178919 & 394891 & 11286 & 240892 & 825988 & 742082 & 67421 & 809503 \\
\hline
\end{tabular}

Source: LFP 2008b

\section{Equitable Forest Product and Benefit Distribution Mechanisms}

Community Forest User Groups have devised benefit distribution mechanisms to respond to the differential needs of forest users of various well-being ranks. CFUGs undertake well-being ranking of member households and forest products are distributed to members accordingly. Households are ranked according to the CFUGs' own sets of criteria developed locally by the members: such as the total amount of land, financial status, educational status and other social standing criteria. In Tarepahar CFUG of Salyan, the households are categorised under the following four categories:

a. Rich households - own land and enough food for 12 months with surplus food, along with good education, high social status, good alternative source of income,

b. Medium households - have food supply for 9-12 months from own land, along with good education, and alternative source of income,

c. Poor households - own land and have food supply for 6-9 months, along with low education, but alternative source of income,

d. Ultra poor households - own land and have food supply for less than 6 months, are illiterate, and work as wage labor for basic survival.

Benefit distribution mechanisms include the distribution of forest products at subsidised rates to the poor households. While forest products are provided on subsidised rates to the poor families, sometimes free access is given to poor single women and ultra poor families. In the case of Mahila (Womens) CFUGs of Kalimati Rampur, forest products used to be distributed equally among the users for several years. Recently, they have decided to manage equitable distribution of forest products. Timber is sold at 50 percent of actual price to the user of $D$ category, at 65 percent to $C$ category and with no charge to the homeless users. In a recent field visit, Ms Parbati Basnet, member of Bhaiyadevi CFUG, Salyan said to the lead author: "It was very difficult for me to maintain 'hand to mouth' (managing food for survival) and I had to search for household works in others' houses everyday. Now CFUG committee has made provisions for collecting fuelwood on subsidised rates (which are much lower than others) for poor households like me. I purchase fuel wood at NRs 10 per bhari (bundle) and sell at NRs 150 per bhari in nearby market. I am now generating income from selling of fuelwood. Now I don't need to work in anyone's house ".

As a result of $A / S M$ activities, favorable changes in the rules of forest distribution have been 
achieved in the LFP area. In Salyan, out of $20790 \mathrm{HHs}, 15076 \mathrm{HHs}$ were benefited from the newly introduced equitable benefit sharing mechanisms. This figure is nearly about 73 percent of the HHs, of which 11 percent (2195 $\mathrm{HHs}$ ) is rich, 20 percent ( $4054 \mathrm{HHs}$ ) is medium, 27 percent $(5552 \mathrm{HHs})$ is the poor, and 16 percent ( $3274 \mathrm{HHs}$ ) were found to be from the very poor category. If we lump poor and very poor together as the poor, the benefit derived by the category of the poor is greater than that of the rich one. The benefit received in case of grasses and fuelwood is greater among the poor. The total bhari of grass received by the poor class is 8081 bhari per year; this is more than that of the non-poor which is about 11 percent of the total bhari of grass received. Similarly, 45468 bhari more fuelwood is received by the poor than that of the rich, which is greater nearly by about 17 percent of the total fuelwood received by all four category (LFP 2008c).

\section{DISCUSSION}

The evidence presented in the previous section shows that through animation and social mobilisation, it is possible to facilitate fairer and equitable negotiation of rules regarding forest management and benefit sharing. However, the sustainability of this outcome in the long run is still questionable. At least three issues are identifiable in this regard.

First, there is still a lack of enabling policy framework to promote pro-poor forest management. Whereas poor communities want benefit from the allocated land in the short span by planting agro-forestry crops, the CF legislation does not allow the planting of annual crops on community forest land. Poor users are encouraged by DFO staff to plant forest/ wild crops, which are not always preferred by and compatible to the needs of the poor. Section 49 under article 11 of Forest Act clearly states that no person shall attempt to deforest, plough, dig or cultivate the land of forest area and construct house or hut (See page no. 9 and 15 of Forest act 1993).
Some of the foresters working in the programme area even argue that plantation of NTFPs like cardamom in CF land reduces biodiversity. It is indeed an irony that broader government policy favors poverty reduction through community forestry, but in the actual practice, the poor are not allowed to cultivate agro-forestry crops which they prefer. Moreover, there is widespread perception among forest users that government retains authority (overriding the provision of Forest Act 1993) while giving the responsibility for the management of forest to communities.

Second, tenure security remains a critical issue in relation to providing sustained incentives to the poor to invest in the forest land allocated to them. Currently, the tenure is defined through an agreement between the poor and the CFUG committee, but there is no regulatory provision for this. Since there is generally a high demand for forest land among the user households of all wealth categories, there are chances that such community level agreements with the poor and excluded groups are easily reverted back under local pressures and politics. The pro-poor innovation can sustain in the long run only when there is strong power built up in favor of the poor locally and district levels. The achievements mentioned above are the result of active facilitation support of LRPs and animators, who need to be supported by district level institutions beyond the project to ensure sustainability of pro-poor innovations.

Third, there is lack of research to identify and develop agro-forestry models that are ecologically sustainable, and can also meet the needs of the poor. Before any meaningful policy dialogues can be initiated, there is a need to create and innovate some agro-forestry models on CF. In depth study to analyse the potential species for land allocation is lacking.

Fourth, as Adhikari (2002) argues, poor users do not actually benefit when all opportunity costs are accounted for in the assessment of costs and benefits of forest management. So even the seemingly equitable provisions may not actually reflect the degree of equity that the poor users 
really want. Thus creating equitable rules is a continuing challenge. Until and unless the balance between the elite and the poor is managed, it is difficult to maintain equitable distribution of benefits.

\section{CONCLUSION}

This paper concludes that through continuous sharing, deliberation and negotiation among the poor and non-poor members of CFUGs, management of community forests can be made equitable. We have provided empirical evidence on the process and outcomes of how facilitation support enable the poor to have equitable access to community forests. Facilitation/ social mobilisation are essential to empower the disempowered and voiceless to come into mainstream. This has resulted in the creation of special management and use right to the poor and excluded groups. The special tenure lead to active management of forest accompanied by increased availability of forest products. However, strong policy back-up with clear guidelines is needed. Moreover, replication of the land allocation mechanism on a large scale, innovation of best practices in the field level and proper facilitation and service delivery to the CFUG on proper time and in simple manner are some of the basic requirements to be fulfilled.

The revised OPs and newly-prepared OPs for community forests have become more inclusive and equitable. Various pro-poor forest management practices including poor-focused enterprises have been initiated. Facilitation support by locally based resource persons or LRPs has contributed to improvements of operational plans, awareness raising, forest management skills development and strong monitoring mechanism. However, there is still a need to provide more effective support to the communities to elaborate sustainable forest management plans and to establish clear, transparent, fair and simple benefit sharing mechanism.

This study also found that co-ordination among the different organisations and line agencies is an essential aspect of the success of pro-poor community forestry process. Equitable forest product and other benefit distribution mechanisms can only be achieved if clear provisions in acts and regulation are made, along with better co-ordination among implementing agencies. The main lesson learnt from this analysis is that benefit sharing at the local level needs to be improved by better understanding of the social structure of communities, providing a legal framework for community forestry committees, developing criteria and indicators to monitor benefit sharing, and development of effective conflict management mechanisms.

\section{REFERENCES}

Adhikari, B. 2002. Property Rights and Natural Resource: Socio-economic Heterogeneity and Distributional Implications of Common Property Resource Management in Nepal. UK: Environment Department, The University of York.

Adhikari, J.R. 2001. Community Based Natural Resource Management in Nepal with Reference to Community Forest: A Gender Perspective, a Journal of the Environment, 6(7): 9-22.

Agarwal, B. 2001. Participatory Exclusions, Community Forestry, and Gender: An Analysis for South Asia and a Conceptual Framework. World Development, 29(10): 1623-1648.

Bista, D.B. 1991. Fatalism and Development: Explorations in Political Theory. New Delhi: Sage Publications.

Branney, P. \& Yadav, K.P. 1998. Changes in Community Forests Condition and Management 1994-1998: Analysis of Information from the Forest Resource Assessment Study and Socio-Economic Study in the Koshi Hills. Project Report G/NUKCFP/32. Kathmandu: NUKCFP.

Dev, O.P., Yadav, N.P., Springate-Baginski, O. \& Soussan, J. 2003. Impacts of Communtiy Foestry on Livelihoods in the Middle Hills of Nepal. Journal of Forest and Livelihood, 3(1): 64-76.

Hayu, T.B. \& Pokharel, B.K. 2004. Contribution of NGOs in Community Forestry and Good Governance: The Experience of Nepal Swiss Community Forestry Project. Proceedings of Fourth National Workshop on Community Forestry, Kathmandu: Department of Forest. 
HMGN 2002. Tenth Five-year Plan (2002-2007). Kathmandu, Nepal: National Planning Commission.

Kanel, K., Shrestha, K., Acharya, K.P. \& Sharma, R. 1999. The Bharkhore Community Forest: a Case Study from Nepal. A paper presented at the Mie Workshop on Case Study on Model Forests for Field-Level Application of Sustainable Forest Management held in Japan, March 23-27, 1999.

Kanel, K.R. 2004. Twenty Five Years of Community Forestry: Contribution to Millennium Development Goals (Eds.), Proceedings of the Fourth National Workshop on Community Forestry. [pp 5]

Khanal, K.P. 2002. Under Utilisation in Community Forestry: A Case Study from Lalitpur District, Banko Janakari, 12(2): 26-32.

Kothari, S. 1999. Inclusive, Just, Plural, Dynamic: Building a Civil Society in the Third World. In: D. Eade (Ed.) Development and Social Action. Oxford: Oxfam. [pp 34-53]

LFP 2004a. What is LFP Doing to Achieve and Enhance Good Governance at CFUG and Service Providers' Level? Note Prepared in a Pre-national Workshop, Kathmandu, Nepal.

LFP 2004b. Innovations for Pro-Poor Community Forestry: Community Forest Land Allocation. Kathmandu: Livelihoods and Forestry Programme.

LFP 2006. Pre Mid-Term Review Study of LFP's Sustainable Forest Management Programme. Kathmandu: Livelihoods and Forestry Programme.

LFP 2007. LFP's Animation and Social Mobilisation: Empowering Local Communities to Access Benefits and Resources. Kathmandu: Livelihoods and Forestry Programme.

LFP 2008a. Annual Report, Unpublished Report. Kathmandu, Nepal: Livelihoods and Forestry Programme.

LFP 2008b. Synthesis of LFP's SFM Activities, Unpublished Report. Kathmandu, Nepal: Livelihoods and Forestry Programme.

LFP 2008c. Forest Management REPORT, Unpublished Report. Salyan: Livelihoods and Forestry Programme.

Malla, Y.B. 2000. Impact of Community Forestry Policy on Rural Livelihoods and Food Security in Nepal. Unasylva, 51(202): 37-45.
Malla, Y.B. 2001. Changing Policies and the Persistence of Patron-Client Relations in Nepal: Stakeholders' Response to Change in Forest Policies. Environmental History, 6(2): 287-307.

Malla, Y.B., Neupane, H.R. \& Branney, P. 2003. Why aren't Poor People Benefiting more from Community Forestry? Journal of Forest and Livelihood, 3(1): 78-91.

Neupane, H.R. 2000. Factors that Influence Poorer Households Access to Forest Products from Community Forests: An Analysis of Decisionmaking and Benefit Sharing Process, $A$ thesis submitted for M. Phil. UK: University of Reading.

NPC 2003. Poverty Reduction Strategy Paper. Kathmandu: National Planning Commission (NPC).

NPC 2007. Three Year Interim Plan. Kathmandu: National Planning Commission, Government of Nepal.

PCR 2008. Project Completion Report. Salyan: Livelihoods and Forestry Programme.

Rai-Paudyal, B. 2008. Agrarian Structure and Distributive Outcomes: A Study of Community Forestry in Nepal. PhD Thesis. The Hague: Institute of Social Studies.

Singh, V.P. 2002. Active versus Passive Management: Issues for Sustainable Development of Community Forestry in the Mid-hills of Nepal. Banko Janakari, 12(1): 62-70.

Springate-Baginski, O., Dev, O.P., Yadav, N.P. \& Soussan, J. 2003b. Community Forest Management in the Middle hills of Nepal: The changing context. Journal of Forest and Livelihood, 3(1): 9-20.

Timsina, N.P. \& Luintel, H. 2003. Equity and Social Justice in Natural Resource Management, A Discussion Note. Kathmandu: ForestAction Nepal.

Timsina, N.P. \& Paudel, N.S. 2003. State verses Community: A Confusing Policy Discourse in Nepal's Forest Management, Journal of Forest and Livelihood, 2(2): 8-16.

Wagle, S. 2002. Contribution of Community Forestry to the Livelihood of Local Participants in the Middle Hills of Nepal: A Case Study of Makawanpur District, An M. Sc Thesis. Thailand: Asian Institute of Technology, Bangkok. 